\title{
OLENA LUGINA
}

Poznań

\section{O krok bliżej do Unii - Nowa Umowa Stowarzyszeniowa między Ukrainą a UE}

Unia Europejska zajmuje w polityce zagranicznej Ukrainy jedno z priorytetowych miejsc. Jeszcze na początku lat dziewięćdziesiątych, a więc wkrótce po uzyskaniu swojej niepodległości w 1991 roku, Ukraina uznała integrację ze Wspólnotą Europejską wraz z rozwojem demokratycznego społeczeństwa obywatelskiego oraz gospodarki rynkowej za swój cel strategiczny, co znalazło odzwierciedlenie w wielu dokumentach tak państwowego, jak i międzynarodowego charakteru. Od tego czasu relacje z Unią Europejską przeszły długą drogę i podążają w dobrym kierunku, powoli przybliżając Ukrainę ku realizacji jej celu - członkostwu we Wspólnocie Europejskiej. Czy uda się kiedykolwiek Ukrainie osiagnnąć ten cel - pokaże czas. W dzisiejszych warunkach pełnoprawne członkostwo Ukrainy w Unii jest celem długoterminowym ze względu na komplikacje, które występują tak w samej Ukrainie (kryzys polityczny i gospodarczy), jak i w Unii Europejskiej (problemy z ratyfikacją Traktatu lizbońskiego i czasowa niegotowość Unii do dalszego poszerzenia).

Obecnie relacje Ukrainy z UE są na etapie negocjacji nowej umowy, która powinna zastąpić Umowę o Partnerstwie i Współpracy (UPW). W ciągu dziesięciu lat, od momentu wejścia w życie w 1998 roku, UPW była „szkieletem” stosunków Kijowa z Brukselą. Podczas Szczytu Ukraina-UE w 2006 r. zostało ustalone, iż UPW będzie automatycznie przedłużana co roku do momentu ratyfikacji nowej wzmocnionej umowy o współpracę między Ukrainą a UE, która zastąpi Umowę o Partnerstwie i Współpracy z 1994 r. Jako instrument polityczny w ramach danej umowy w lutym 2005 roku został przyjęty Wspólny Plan Działań Ukraina-UE, który ma na celu regulację relacji Ukraina-UE na wszystkich płaszczyznach współpracy. Plan Działań miał pełnić funkcję głównego instrumentu politycznego do marca 2009 r., natomiast później według założeń obu stron powinno było zostać wypracowane nowe narzędzie polityczne, które zastąpiłoby obecny Plan Działań i stworzyłoby warunki dla implementacji nowej umowy między Ukrainą a Unią Europejską.

Negocjacje w sprawie Nowej Umowy Stowarzyszeniowej (NUS) między Ukrainą a UE zostały rozpoczęte 5 marca 2007 roku. Żeby lepiej zrozumieć istotę relacji Ukrainy z UE na obecnym etapie niezbędnym wydaje się zaprezentowanie ukraińskiej wizji na temat przyszłej Umowy Stowarzyszeniowej, która została przedstawiona w Ustawie Rady Najwyższej „O rozpoczęciu negocjacji między Ukrainą a UE odnośnie zawarcia nowej umowy" z 22 lutego 2007 roku ${ }^{1}$. Otóż według tej ustawy realizacja nowej umowy

1 Постанова Верховної Ради Украӥни Про започаткування переговорів між Україною та ЄC щодо укладення нового базового договору N 684-V від 22 лютого 2007 року, http://zakon1.rada.gov.ua/cgi-bin/laws/main.cgi?nreg=684-16. 
powinna sprzyjać wszechstronnemu i stopniowemu przybliżeniu Ukrainy do Unii Europejskiej w sferach polityki, bezpieczeństwa, handlowo-ekonomicznej, socjalnej, ustawodawstwa, co odpowiada dhugoterminowym interesom Ukrainy oraz oczekiwaniom ukraińskich obywateli. Jedno z centralnych miejsc w Ustawie zajmuje powołanie na apel Parlamentu Europejskiego do Rady UE, Komisji UE oraz państw członkowskich UE, w którym PE nawołuje do rozważenia innych form stowarzyszenia z Ukrainą poza zachodami w ramach Europejskiej Polityki Sąsiedztwa oraz nadanie wyraźnej perspektywy członkostwa narodowi ukraińskiemu. Ten apel został przedstawiony w Rezolucji Parlamentu Europejskiego z 13 stycznia 2005 r. W Ustawie zostało podkreślone, iż idea europejska staje się na Ukrainie istotnym elementem społecznej świadomości. W celu otrzymania w przyszłości członkostwa w UE Ukraina zobowiązuje się adaptować ukraińskie ustawodawstwo do wymogów UE oraz pogłębić współpracę międzyparlamentarna.

W ramach przejścia na nowy etap relacji z Unią Europejską strona ukraińska apeluje do UE by uwzględnić postęp, który został osiagnięty w ich relacjach, i odpowiednio określić perspektywy ukraińskiego postępu na drodze ku UE, m.in.: konstatować otwartość UE dla członkostwa Ukrainy, jak i jakiegokolwiek europejskiego państwa, które uznaje i szanuje zasady wolności, demokracji, rządy prawa oraz przestrzega praw człowieka; wprowadzić etapy integracji Ukrainy z UE w poszczególnych sferach relacji: politycznej, gospodarczej, energetycznej, ustawodawczej, sferze bezpieczeństwa i in.; sprzyjać na podstawie nowej umowy dynamicznemu rozwojowi i pogłębieniu relacji między Ukrainą a UE aż do momentu otrzymania przez Ukrainę pełnoprawnego członkostwa w UE i inne. Takie oczekiwania wyraziła wobec Nowej Umowy Stowarzyszeniowej strona ukraińska.

Żeby udzielić odpowiedzi na pytanie, czy Nowa Umowa Stowarzyszeniowa w pełni sprosta oczekiwaniom państwa ukraińskiego, warto się przyjrzeć procesowi negocjacyjnemu.

Pierwszy Raport dotyczący postępu w negocjacjach w 2007 roku został przedstawiony we wrześniu 2007 roku podczas Szczytu Ukraina-UE w Kijowie. Od tej pory miało miejsce osiem rund negocjacji w sprawie Umowy Stowarzyszeniowej. Negocjacje odbywają się podczas posiedzeń plenarnych oraz spotkań czterech grup negocjacyjnych, które są podzielone według rozdziałów przyszłej umowy, a mianowicie: a) dialogu politycznego oraz polityki zagranicznej i bezpieczeństwa; b) ustawodawstwa, wolności oraz kwestii bezpieczeństwa; c) współpracy gospodarczej i sektorowej; d) podpisania Umowy o Strefie Wolnego Handlu (od lutego 2008 roku). Negocjacje na temat pogłębionej oraz wszechstronnej strefy wolnego handlu jako elementu kluczowego nowej Umowy Stowarzyszeniowej zapoczątkowano w 18 lutego 2008 roku po potwierdzeniu członkostwa Ukrainy w Światowej Organizacji Handlu przez Radę Generalną WTO 5 lutego $2008 \mathrm{r}$.

W trakcie negocjacji nad Nową Umową Stowarzyszeniową między Ukrainą a Unią Europejską obie strony osiagnęły szerokie porozumienie odnośnie celów, wartości oraz głównych zasad Umowy. Podjęto także decyzję, że Umowa między Ukrainą a UE będzie Umową Stowarzyszeniową odzwierciedlającą zobowiązania obu stron do pogłębiania współpracy za pomocą stowarzyszenia, które przewidywałoby tak wzajemne prawa, jak i obowiązki².

2 2nd Joint Progress Report. Negotiations on the EU - Ukraine Association Agreement, Представництво Європейської Комісії в Україні, Політичні відносини [online], wejście na 
Biorąc pod uwagę ogólny kontekst polityczny oraz aspiracje państwa odnośnie członkostwa w UE ukraińska strona postawiła sobie za cel osiagnięcie nowego, wysokiego poziomu relacji, przechodząc od zasad partnerstwa i współpracy do zasad stowarzyszenia politycznego oraz integracji gospodarczej. W odpowiedzi na taką deklarację ze strony Ukrainy UE zaznaczyła, iż NUS powinna zabezpieczyć najbardziej możliwe zbliżenie Ukrainy do UE, ale ,nie będzie określała jakiegokolwiek możliwego rozwoju relacji między Ukrainą i UE w przyszłości”3. Obie strony się zgodziły, że rozpatrywanie danej kwestii powinno być przełożone na późniejszy etap negocjacji.

Szerokie porozumienie strony osiagnęły także w kwestii instytucji, które zapewnią wdrożenie w życie umowy po jej ratyfikacji. Na przykład strony doszły do porozumienia, że w przypadkach podejmowania decyzji w kwestiach zaznaczonych w Umowie dane decyzje powinny być zatwierdzone przez Komisję składającą się z przedstawicieli Ukrainy oraz UE. Wydaje się oczywistym, iż kwestie w których wspólna Komisja będzie mogła podejmować takie decyzje, będą ustalane dopiero pod koniec procesu negocjacyjnego ${ }^{4}$.

W kwestiach dialogu politycznego oraz polityki zagranicznej i bezpieczeństwa strony doszły do porozumienia, iż podstawowe cele danej Umowy powinny zawierać polityczne zbliżenie, międzynarodowe bezpieczeństwo oraz rozwiązanie kryzysów, wspólne wysiłki dla zabezpieczenia pokoju, bezpieczeństwa oraz stabilności na kontynencie europejskim, szacunek do zasad demokratycznych, rządy prawa, przestrzeganie praw człowieka i podstawowych wolności oraz rozwój dialogu i współpracy w kwestiach bezpieczeństwa i obrony. Na późniejszym etapie negocjacji zostanie ustalone w jaki sposób lepiej przedstawić ukraińską propozycję odnośnie nawiązywania do kwestii suwerenności, niepodzielności terytorialnej oraz nienaruszalności granicy. Tekst umowy zawiera kwestie kluczowe dla przybliżenia Ukrainy do standardów europejskich, a mianowicie: reformę wewnętrzną, stabilność regionalną, zapobieganie konfliktom, uregulowanie kryzysów, możliwą współpracę wojskowo-techniczną, nierozprzestrzenianie broni masowego rażenia, rozbrojenie i kontrolę nad bronią, walkę z terroryzmem oraz ramy dla prowadzenia dialogu politycznego. Chociaż większa część tekstu tego rozdziału jest już uzgodniona, wciąż pozostają niektóre zagadnienia, które będą rozpatrywane dopiero na późniejszych etapach negocjacji.

Podczas negocjacji nad drugą grupą zagadnień, która obejmuje kwestie ustawodawstwa, wolności oraz bezpieczeństwa stronom prawie udało się sfinalizować negocjacje nad tym rozdziałem Umowy. Drugi rozdział obejmuje swoim zasięgiem zwierzchnictwo prawa, ochronę praw człowieka, ochronę danych osobowych, współpracę w kwestiach migracji, azylu oraz kontrolę granic, przepływ osób, pranie pieniędzy oraz finansowanie terroryzmu, współpracę odnośnie przemytu narkotyków, walkę ze zorganizowaną przestępczością, walkę z terroryzmem oraz współpracę ustawodawczą.

stronę 25.09.2009 r.: http://ec.europa.eu/delegations/ukraine/eu_ukraine/political_relations/index_uk.htm.

${ }^{\overline{3}}$ Спільний звіт про прогрес у переговорах стосовно нової посиленої угоди між Украӥною ma $\epsilon C$, Міністерство Закордонних Справ України [online], wejście na stronę 25.09.2009 r.: $\mathrm{http} / / /$ www.mfa.gov.ua/mfa/ua/publication/content/19158.htm.

4 2nd Joint Progress Report. Negotiations on the EU-Ukraine Association Agreement, op. cit, http://ec.europa.eu/delegations/ukraine/eu_ukraine/political_relations/index_uk.htm. 
Postęp w negocjacjach w sprawie treści tego rozdziału Umowy można określić jako progresywny, aczkolwiek niektóre kwestie jeszcze zostały otwarte do dalszego przedyskutowania, jak na przykład: problem nielegalnego zatrudnienia, przepływ osób.

Ukraińska strona zaznaczyła ważność modyfikacji Planu Działań Ukraina-EU, który został przyjęty 18 czerwca 2007 roku, w sferze prawa, wolności i bezpieczeństwa w celu ,prawidłowego odzwierciedlenia w Nowej Umowie Stowarzyszeniowej dynamiki współpracy między Ukrainą i UE" ". Ponadto Ukraina zaakcentowała swoją chęć zamieszczenia w tekście Nowej Umowy paragrafów, które omawiałyby wprowadzenie wzajemnego reżimu bezwizowego między Ukrainą a UE, wprowadzenie skutecznych mechanizmów współpracy przygranicznej oraz protokołu współpracy sądowej w sprawach cywilnych. Ze względu na wyrażenie przez UE wyraźnych zastrzeżeń wobec zaproponowanych zagadnień, te i inne kwestie będą poruszane w następnych rundach negocjacji.

W grupie prowadzącej negocjacje z zagadnień współpracy ekonomicznej i sektorowej 19 zagadnień z 26 mogą być uznane za uzgodnione, jak m.in.: prawo korporacyjne, sport, turystyka, zarządzanie środkami publicznymi, energetyka łącznie z energetyką jądrową, ochrona środowiska, współpraca transgraniczna i regionalna, edukacja, wychowanie i młodzież, kultura, rozwój naukowo-technologiczny, współpraca makroekonomiczna, współpraca socjalna, polityka przemysłowa oraz polityka przedsiębiorczości, rolnictwo, komunikacja, polityka audiowizualna i inne. Na późniejszych etapach negocjacje będą kontynuowane w dziedzinie podatków, statystyki, ochrony praw konsumentów, społeczeństwa informacyjnego. Podczas pierwszych rund negocjacji udało osiagnąć istotne porozumienie odnośnie celów i elementów współpracy w danych sferach.

Spotkania mające na celu omówienie zasad funkcjonowania strefy wolnego handlu miały miejsce osiem razy od momentu pierwszych negocjacji w lutym 2008 roku. Ostatnia runda odbyła się 5-9 października 2009 r. w Brukseli. Podczas spotkania obie strony podkreśliły konstruktywny charakter rokowań, który pozwolił na osiagnięcie postępu w niektórych rozdziałach potencjalnej umowy. Ukraina o kolejny krok zbliżyła się do stworzenia strefy wolnego handlu, która otworzy nowe możliwości dla handlu i inwestycji oraz będzie sprzyjała zbliżeniu gospodarki ukraińskiej do standardów UE.

Robocze grupy zajmujące się takimi kwestiami, jak sprzyjanie celnej i handlowej współpracy oraz ochrona własności intelektualnej, osiagnęły znaczący postęp w negocjacjach, co w bliższym czasie doprowadzi do zakończenia negocjacji nad tym rozdziałem umowy. Podczas tej rundy negocjacji jednym z najważniejszych pytań na porządku dziennym znowu była liberalizacja taryf. Obie strony przedstawiły swoje pozycje oraz potwierdziły gotowość do kolejnej rundy negocjacji, która była zaplanowana na 7-11 grudnia 2009 r. w Kijowie. Uczestnicy negocjacji również zwrócili uwagę na takie pytania, jak polepszenie transparentności, polityce konkurencyjnej oraz pracowali nad stworzeniem nowych, ulepszonych możliwości dla handlu usługami oraz inwestycji ${ }^{6}$.

\footnotetext{
5 Спільний звіт про прогрес у переговорах стосовно нової посиленої угоди між Украӥною ma $E C$, op. cit., http://www.mfa.gov.ua/mfa/ua/publication/content/19158.htm.

6 5-9 жовтня в Брюсселі між делегаціями Свропейської Комісії та України відбувся 8-ий раунд переговорів щуодо створення зони вільної торгівлі (ЗВТ) між ЄС та Украйною, Пре-
} 
Podpisanie przez Ukrainę Umowy o strefie wolnego handlu z Unią Europejską ma ogromne znaczenia dla rozwoju ukraińskiej gospodarki. Jako jeden z największych rynków świata UE proponuje Ukrainie perspektywę uczestnictwa w swojej gospodarce poprzez liberalizację handlu. Strefa wolnego handlu będzie sprzyjała gospodarczemu zbliżeniu Ukrainy i Unii Europejskiej oraz modernizacji branży gospodarki narodowej i dokonaniu wewnątrzpaństwowych reform.

Mówiąc o stanowisku Unii Europejskiej odnośnie aspiracji Ukrainy zostania pełnoprawnym członkiem Wspólnoty należy odnotować ostrożność w podejmowaniu konkretnych decyzji, a czasami nawet pewien sceptycyzm. Mimo presji strony ukraińskiej UE stara się unikać konkretnych deklaracji dotyczących członkostwa Ukrainy we Wspólnotach, ale jednocześnie ciągle stwarza iluzje niezbędne dla utrzymania na Ukrainie zainteresowania podążania w tym kierunku. Unia Europejska jest przede wszystkim zainteresowana tym, żeby państwa, z którymi ma wspólne granice, cechowała stabilność i zamożność. Dlatego Ukraina została objęta Europejską Polityką Sąsiedztwa, która jednak nie posiada żadnego zapisu o możliwości członkostwa państw, do których dana inicjatywa jest skierowana. Czy w Nowej Umowie Stowarzyszeniowej znajdzie się zapis o członkostwie w Nowej Umowie Stowarzyszeniowej zależeć będzie w dużym stopniu od samej Ukrainy.

Żeby kandydatura Ukrainy została rozpatrzona przez UE pod kątem nadania jej członkostwa we Wspólnocie, Ukraina musi spełniać wymagania UE, które wiążą się z długim szeregiem reform przede wszystkim w ustawodawstwie państwowym. Z kolei dokonanie zmian na płaszczyźnie ustawodawczej wymaga nienagannej pracy Parlamentu, dobrze zorganizowanej współpracy między władzą ustawodawczą a wykonawczą. Niestety panujący od dłuższego czasu na Ukrainie kryzys polityczny uniemożliwia dokonanie szybkich i istotnych zmian w celu przybliżenia Ukrainy do standardów europejskich. Sytuacja na Ukrainie również się komplikuje z uwagi na kryzys gospodarczy w państwie, który jest konsekwencją światowego kryzysu finansowego ${ }^{7}$.

Mimo że wielu z zaplanowanych zmian nie zostało dokonanych Unia Europejska na ostatnim posiedzeniu Rady Współpracy UE-Ukraina 17 czerwca 2009 r. odnotowała postęp w relacjach między UE a Ukrainą. Rada Współpracy podkreśliła również znaczny postęp w negocjacjach odnośnie Nowej Umowy Stowarzyszeniowej między UE a Ukrainą. Unia Europejska zachęca Ukrainę do kontynuowania prób stabilizacji sytuacji gospodarczej i finansowej w państwie przy współpracy z MWF oraz innymi międzynarodowymi instytucjami finansowymi. Podczas spotkania została po raz kolejny podkreślona nadzwyczajna ważność przeprowadzenia reformy konstytucyjnej przy wykorzystaniu wskazówek Komisji Wenecjańskiej ${ }^{8}$.

дставництво Європейської Комісії в Україні [online], wejście na stronę 9.10.2009 r.: http://ec.europa.eu/delegations/ukraine/eu_ukraine/political_relations/index_uk.htm.

7 Postęp w dokonaniu zmian na Ukrainie w celu przybliżenia państwa do standardów Unii Europejskiej został szczegółowo opisany w Raporcie Komisji Europejskiej na temat Wdrażania Europejskiej Polityki Sąsiedztwa na Ukrainie w 2008 r. z 23 kwietnia 2009 r. oraz we wspólnym Raporcie na temat realizacji Planu Działań Ukraina-UE z marca 2008 r.

8 EU-Ukraine Cooperation Council, Thirteenth Meeting, Luxembourge, 16 june 2009, EU Press Release: http://www.consilium.europa.eu/uedocs/cms_Data/docs/pressdata/en/er/108533.pdf. 
Ze względu na przyszłe wybory Prezydenta Ukrainy, które będą miały miejsce w styczniu 2010 r., UE zaznaczyła, iż Ukraina powinna zadbać o zachowanie reputacji państwa przeprowadzającego wybory w sposób demokratyczny według standardów międzynarodowych. Nie ma nic dziwnego w tym, iż styczniowe wybory prezydenckie budzą w Unii Europejskiej wielkie zainteresowanie. W zależności od tego, kto obejmie stanowisko głowy państwa, będzie wiadomo, w jakim kierunku będzie podążała Ukraina w swojej polityce zagranicznej w ciągu najbliższych pięciu lat, a może to być kierunek pro-europejski, pro-rosyjski lub wielowektorowość. Od wyboru priorytetów współpracy zagranicznej będzie bezpośrednio zależał rozwój relacji między Kijowem a Brukselą. 